\title{
Open Ended Approach: An Exploration of CriticalThinking Skill
}

\author{
${ }^{1}$ Nelly Rhosyida, ${ }^{2}$ Trisniawati, ${ }^{3}$ Flora Grace Putrianti \\ ${ }^{1}$ nelly.rhosyida@ ustjogja.ac.id, ${ }^{2}$ trisniawati.87@gmail.com, ${ }^{3}$ dgrace.p@ gmail.com \\ 1,2,3 UniversitasSarjanawiyataTamansiswa Yogyakarta, Indonesia
}

\begin{abstract}
This study is aimed to describe the mathematical critical thinking skills of PGSD students with an open ended approach. Subjects in this study were student grade4. The method used in this study is a quasi-experimental design. Data analysis using independent sample $t$ test and categorization based on aspects of critical thinking skills. The average score of the open-ended class is higher than the average score of the class with group discussion learning, that is $73,18>66,72$. It means the experimental class learning outcomes are higher than the control class. The critical thinking skills of open ended class is in high category, while group discussion class is in the middle category. The stages of recognize assumption, the mastery percentage of the experimental class is $88,27 \%$ while the control class is $75,50 \%$. At the evaluate the argument stage, the experimental class is $74,49 \%$ while the control class is $53,50 \%$. At the stage of draw conlussion, the percentage of the experimental class is $23,47 \%$ while the control class is $9 \%$. Sig. 2 tailed in the t-test results is $0.041<0.05$ which means that using the open ended approach is more effective.
\end{abstract}

Keywords: Exploration; Critical Thinking Skill; PGSD; Open Ended Approach.

\section{Introduction}

Mathematics is a basic science that plays an important role in the development of science and technology. Recognizing the important role of mathematics in various aspects of life, mathematics becomes one of the objects studied at every level of education. In mathematics learning, students not only learn mathematics material but also learn to deal with problems and challenges in social life [1]. On a daily life, people were faced with decisions that require reasoning, understanding, interpreting, analysing and evaluating information before them. This process involves critical thinking because it would enable one to take reliable and valid decisions, act ethically, and be able to adapt to changes in any given environment[2]. Expert opinion given above shows how important the role of critical thinking skills in a person, in particular for the development of the capacity of a student, as a subject as well as in a learning process [3]. 
In teaching Mathematics in schools, Critical Thinking needs to be integrated and emphasized in the curriculum so that students can learn the skills and apply it to improve their performance and reasoning ability [2]. The same things, developing critical thinking skills is one of the goals of education, as stated in the 2013 curriculum [4] which states that one of the goals of the 2013 curriculum is to improve the mindset related to learning that develops critical thinking skills. Unfortunately, Construction of learning more teacher-centered response to the condition where students only receive the information without considering their ability to think. It has undercut the ability of students in an effort to do the analysis and synthesis. The main principle of learning is to provide a great opportunity so that students can develop the ability to think and manage this capability so that there is a meaningful learning.

But in reality students' critical thinking skills are still low. Based on the results of observations in several subjects related to mathematics in the PGSD Study Program at Sarjanawiyata Tamansiswa University, most students were unable to solve problems related to daily life. In addition, based on research results [5] shows that the ability to solvemathematical problems of PGSD students is low. Students have difficulty in solving non-routine questions. some students have not been able to understand, plan solutions, or provide logical arguments in solving problems correctly. Even though, a man who can think critically bring up the vital questions and problems and formulate it clearly and precisely [6].

The mathematics learning process all this time was using group discussions. This learning carried out strives for student activeness in learning. But it has not been able to optimize students' criticalthinkingskill. Mathematical learning that must be done should be the process of constructing knowledge.According to [7], "learning is the construction of knowledge; memory is the storage of knowledge; and thinking is the logical manipulation of knowledge. It requires changes in various components of education, such as the approach to mathematics learning. The learning approach developed must provide wide opportunities for students to explore all their skill and experiences, one of which is an open-ended approach. The type of problem used in learning process with open-ended approach is not routine and open problem. Open process means that the task type has several correct ways. Open end products mean that the task type has multiple answer possibilities [8].This opinion shows that in an open-ended approach requires the ability to solve mathematical problems given. So it can be concluded that one approach to learning that is thought to be able to develop mathematical critical thinkingskill is open-ended approach.

\section{Literature Review}

Critical thinking is the intellectually disciplined process of actively and skillfully conceptualizing, applying, analyzing, synthesizing, and/or evaluating information gathered from or generated by, observation, experience, reflection, reasoning, or communication, as a guide to belief and action [9]. This statement emphasizes that the ability to think critically is an intellectual process that guides a person in action. [10] suggested that critical thinking resulted from the interaction of a set of dispositive toward critical thinking: seeking a clear 
statement of the questions, seeking reasons, trying to be well informed, and trying to remain relevant the main point.

The steps Watson-Glatser examine how students with critical thinking when they solve a problem areRecognize Assumptions, Evaluate Arguments and Draw Conclusions (Inference, Deduction, and Interpretation). The new model described as the new RED models as follows [11].

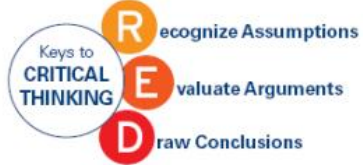

Figure 1. The New RED Watson-Glatser Models

[12] state that group discussion is a regular process that involved a group of people and informal face-to-face interaction with various experiences or information, conclusions or problem solving. The discussion method is a way of delivering the subject matter by exchanging ideas or discussing it, both between lecturers and students or fellow students. Open-ended learning approach is a learning approach that uses open-ended problems. This is the same with [13] which states that open-ended approach is a learning approach that uses open-ended problems, open-ended problems have many solutions or many approaches or ways to find a solution. According to [14] in an open-ended approach, teacher provides students with somemultiple sollution problem or the answer to the solution is not only one way. Then the teacher utilizes a variety of problem approaches to provide experience to students in finding or finding something new by combining all the knowledge, skills, and mathematical ways of thinking that have been studied previously. More of that, [15] "This approach started with having students engaging in open-ended problems which are formulated to have multiple correct answers" incomplete "or" open ended". In terms of teaching method, one "open-ended" problem is posed to the students first, then, proceeds by using many correct answer to the given problem to provide experience in finding new problems during the problem solving process.

\section{Material \& Methodology}

This research is a quasi-experimental research with pretest-posttest non equivalent group design. This study involved one factor, namely the learning approach (open-ended and group discussions) and two responses, namely critical thinking skills. The design of this study is as follows 
Table 1. Research Design

\begin{tabular}{cccc}
\hline Group & Pretest & Treatment & Posttest \\
$\mathbf{E}_{\mathbf{1}}$ & $\mathrm{T}_{1}$ & $\mathrm{X}_{1}$ & $\mathrm{O}_{1}$ \\
$\mathbf{E}_{\mathbf{2}}$ & $\mathrm{T}_{1}$ & $\mathrm{X}_{2}$ & $\mathrm{O}_{2}$ \\
\hline
\end{tabular}

Information:

$\mathrm{E}_{1} \quad$ : experimental group (open-ended approach)

$\mathrm{E}_{2} \quad$ : control group (learning with group discussion)

$\mathrm{T}_{1}$ : pretest critical thinking skill experiment group

$\mathrm{T}_{2} \quad$ : pretest critical thinking skill control group

$\mathrm{O}_{1} \quad$ posttest critical thinking skill experiment group

$\mathrm{O}_{2} \quad$ posttest critical thinking skill control group

$\mathrm{X}_{1}$ : open-ended approach

$\mathrm{X}_{2}$ : learning with group discussion

The steps taken in this study are: 1) Some learning groups (classes) are taken randomly to determine the experimental group or control group. 2) Give the pretest of critical thinking skill to each group at the same time. 3) Conduct learning with an open-ended approach in the experimental class and group discussions in the second group. 4) Give a posttest of critical thinking skills to both groups at the same time. and 5) analyzing data from the results of pretest and posttest to test hypotheses and get conclusions from the study.

This research was conducted in PGSD Sarjanawiyata Tamansiswa University. The subjects of this study were students of the fourth semester PGSD on the subject of mathematics learning. The data collection method is the test method. This method is used to obtain data regarding the achievement of critical thinking skill of students of PGSD. The form of test questions used in the form of a description problem. Data analysis was conducted to find out whether the open-ended approach was effective or not, and the group discussion was studied in terms of students' critical thinking skill. Data analyzed by independent t-test is posttest data. Before being analyzed, the data must meet the assumption test that are normality test and variance homogeneity.

\section{Results and Discussion}

\subsection{Result}

The data in this study include data about students' critical thinking skill. Learning is done in two different classes. Class $4 \mathrm{~A}$ as an experimental class with an open-ended approach. Class $4 \mathrm{~F}$ as a control class with group discussion method. The researcher then gives the critical thinking test to the two groups at the same time.The research results obtained in the form of quantitative data in the form of scores of critical thinking skills test results. The results score data will later describe the achievement of students' mathematical critical thinking skills that will be included in the high, middle, or low category. The score of critical thinking skills test results obtained can be described as follows. 
Table 2. Description of CTS Test Score

\begin{tabular}{cccccc}
\hline Kelas & $\mathbf{N}$ & Means & Varians & Minimum & Maksimum \\
\hline Eksperimen & 49 & 73,18 & 240.33 & 27,78 & 100 \\
Control & 50 & 66,72 & 332.26 & 27,78 & 94,44 \\
\hline
\end{tabular}

Based on Table 2, it can be seen that the lowest and highest CriticalThinkingSkillsscores obtained by the experimental class (open-ended approach) are 27,78 and 100 with an average of 73,18. For the control group (group discussion) the lowest and highest Critical Thinking Skills scores were 27,78 and 94,44 with an average of 66,72. From the table it can be seen that the average score obtained by the class by learning the open-ended approach is higher than the average score obtained by the class with group discussion learning.

Data of student Critical Thinking Skills scores are then categorized according to the level of critical thinking skill, grouped into 3 categories based on mean and standard deviation. namely as in table 3 as follows.

Table 3.Category of Achievement of Student

\begin{tabular}{cc}
\multicolumn{2}{c}{ Critical Thinking Skills } \\
\hline Score Interval $(\mathrm{X})$ & Category \\
\hline $66,67<\mathrm{X} \leq 100$ & Upper \\
$33,33<\mathrm{X} \leq 66,67$ & Middle \\
$0<\mathrm{X} \leq 33,33$ & Low \\
\hline
\end{tabular}

Achievement of students' problem solving skill based on their categorization is presented in table 4 . This data shows the number of students in the upper, middle, and low categories.

Table 4. Achievement of Student Critical Thinking Skills

\begin{tabular}{ccccc}
\hline & \multicolumn{2}{c}{ Experiment Class } & \multicolumn{2}{c}{ Control Class } \\
& Number of Students & $\%$ & Number of Students & $\%$ \\
\cline { 2 - 5 } Upper & 33 & 67,35 & 23 & 46,00 \\
Middle & 14 & 28,57 & 20 & 40,00 \\
Low & 2 & 4,08 & 7 & 14,00
\end{tabular}

Based on Table 4, it can be seen that from the control class (group discussion) there are 23 students who have critical thinking skill in the high category, 20 students in the middle category, and 7 students in the low category. For the experimental class (open-ended 
approach) there were 33 students who had critical thinking skill in the upper category, 14 students in the middle category, and 2 students in the low category.

The percentage of mastery at each stage of critical thinking skill is presented in Table 5 as follows.

Table 5. Percentage of Students at Each Stage of CTS

\begin{tabular}{|c|c|c|c|c|}
\hline & & \multicolumn{3}{|c|}{$\begin{array}{l}\text { Percentage of the Number of Students Who } \\
\text { Mastered each Stage of critical thinking skill }(\%)\end{array}$} \\
\hline & & $\mathbf{A}$ & B & C \\
\hline \multirow{2}{*}{$\begin{array}{l}\text { Question } \\
\text { Number } 1\end{array}$} & Exp & 89,80 & 83,67 & 18,37 \\
\hline & Control & 70,00 & 60,00 & 4,00 \\
\hline \multirow{2}{*}{$\begin{array}{l}\text { Question } \\
\text { Number } 2\end{array}$} & Exp & 93,88 & 71,43 & 22,45 \\
\hline & Control & 74 & 54 & 20 \\
\hline \multirow{2}{*}{$\begin{array}{l}\text { Question } \\
\text { Number } 3\end{array}$} & Exp & 89,80 & 77,55 & 22,45 \\
\hline & Control & 74 & 48 & 8 \\
\hline \multirow{2}{*}{$\begin{array}{l}\text { Question } \\
\text { Number } 4\end{array}$} & Exp & 79,59 & 65,31 & 30,61 \\
\hline & Control & 84 & 52 & 4 \\
\hline \multirow{2}{*}{ Mean } & Exp & 88,27 & 74,49 & 23,47 \\
\hline & Control & 75,50 & 53,50 & 9,00 \\
\hline
\end{tabular}

Information :

A : recognize assumption

$\mathrm{B}$ : evaluate argument

$\mathrm{C}:$ draw conclussion

Based on table 5, the stages of recognize assumption, the mastery percentage of the experimental class is $88,27 \%$ while the control class is $75,50 \%$. At the evaluate the argument stage, the experimental class is $74,49 \%$ while the control class is $53,50 \%$. At the stage of draw conlussion, the percentage of the experimental class is $23,47 \%$ while the control class is $9 \%$.

The normality test of critical thinking skill test scores is done to find out whether the two classes used in research are normally distributed or not. The statistical analysis used in this study was the Kolmogorov-Smirnov test which was calculated using the SPSS program. The steps for normality testing are as follows:

a) Hypothesis

$\mathrm{H}_{0}$ : the sample comes from a population that is normally distributed

$\mathrm{H}_{1}$ : the sample does not come from a population that is normally distributed

b) Level of significance $(\alpha)$, which is $\alpha=0.05$

c) Criteria for rejection $\mathrm{H}_{0}$ 
The decision making process uses the Sig. that is, if the value of Sig. $<0.05$ then $\mathrm{H}_{0}$ is accepted.

d) Analysis

Table 6. Normality Test Data for CTSTest Score with Kolmogorov-Smirnov Test

\begin{tabular}{ccc}
\hline Class & $\begin{array}{c}\text { Significance } \\
\text { (Sig.) }\end{array}$ & Decision \\
\hline Experiment & 0,200 & Data is normally distributed \\
\hline Control & 0,086 & Data is normally distributed \\
\hline
\end{tabular}

The experimental class test results (open-ended approach) from the critical thinking skill test score data obtained Sig. $=0,200>0,05$, then $\mathrm{H} 0$ is accepted and the results of testing the control class (group discussion) from the critical thinking skill test score data obtained Sig. = $0,086>0,05$, then $\mathrm{H} 0$ is accepted.

\section{Conclusion}

Based on the result sof data analysis with the Kolmogorov Smirnov test, both the data in the experimental class (open-ended approach) and control class (group discussion), both gave the $\mathrm{H}_{0}$ results accepted. This means that both are normally distributed.

After being tested for normality, the critical thinking skill test score data is then tested for homogeneity to find out whether the data from both classes are homogeneous or not. The following is a calculation of the homogeneity test variance of critical thinking skill test score data between experimental class and control class with the help of SPSS program. The test steps for homogeneity of variance are as follows.

a) Hypothesis

$$
\begin{aligned}
& \mathrm{H}_{0}: \sigma_{1}^{2}=\sigma_{2}^{2} \text { (homogeneous variance) } \\
& \mathrm{H}_{1}: \sigma_{1}^{2} \neq \sigma_{2}^{2} \text { (non - homogeneous variance) }
\end{aligned}
$$

b) Level of significance ( $\alpha$ ), which is $\alpha=0.05$

c) Criteria for rejection $\mathrm{H}_{0}$

The decision making process uses the Sig. that is, if the value of Sig. $<0.05$ then $\mathrm{H}_{0}$ is rejected.

d) Analysis

Table 7. Homogeneity Test Data

\begin{tabular}{ccc}
\hline & Significance (Sig.) & Decision \\
\hline CTS test score & 0,163 & Homogen \\
\hline
\end{tabular}


Based on table 7, using a 95\% confidence level, it appears that the sig value $=0.163>0.05$, then $\mathrm{H}_{0}$ is accepted.

e) Conclusion

Based on the results of the analysis with the Levene test, the results were obtained that $\mathrm{H}_{0}$ was accepted. This means that both classes (experimental class and control class) have homogeneous variances.

After the normality test and homogeneity test, the questionnaire data obtained were then tested by hypothesis using the independent sample t test. The steps to test the hypothesis are as follows.

a) Hypothesis

$\mathrm{H}_{0}: \mu_{1} \leq \mu_{2}$ (mathematics learning using an open-ended approach is no more effective than mathematics learning using group discussion in terms of students' critical thinking skill).

$\mathrm{H}_{1}: \mu_{1}>\mu_{2}$ (Mathematics learning using an open-ended approach is more effective than mathematics learning using group discussion in terms of students' critical thinking skill).

b) Level of significance $(\alpha)$, which is $\alpha=0.05$

c) Criteria for rejection $\mathrm{H}_{0}$

The decision making process uses the Sig. that is, if the value of Sig. $<0.05$ then $\mathrm{H}_{0}$ is rejected.

d) Analysis

After testing the independent sample t-test, the following data were obtained.

Table 8. Independent Sample T-test of Student CTS

\begin{tabular}{lll}
\hline & Significance (Sig.) & Decision \\
\hline CTS score & 0,041 & $\mathrm{H}_{0}$ rejected \\
\hline
\end{tabular}

Based on table 8, using a 95\% confidence level it appears that the Sig. $=0.041<0.05$, then $\mathrm{H}_{0}$ is rejected.

e) Conclusion

Based on the results of the analysis by testing the independent sample t-test, the results obtained were that $\mathrm{H}_{0}$ was rejected. This means that mathematics learning using the Openended approach is more effective than mathematics learning using group discussion in terms of students' critical thinking skill. 


\subsection{Discussion}

Based on the results of the research, learning with an open-ended approach is more effective than learning with group discussion. it can be seen from the following result. The average score obtained by the class by learning the open-ended approach (experimental group) is higher than the average score obtained by the class with group discussion learning (control group), that is $73,18>66,72$. The average critical thinking score of open ended class include in high category, while group discussion score is in middle category. Both of two groups got the same minimum score, but experimental group get higher than control group in case of maximum critical thinking skills score.

The group discussion class there are 23 students (46\%) who have critical thinking skill in the high category, 20 students (40\%) in the middle category, and $7(14 \%)$ students in the low category. For the experimental class (open-ended approach) there were 33 students $(67,35 \%)$ who had critical thinking skill in the upper category, 14 students $(28,57 \%)$ in the middle category, and 2 students $(4,08 \%)$ in the low category. In the upper categories, open ended class get higher percentage than group discussion. Conversly, in the middle and low categories, open ended class get lower percentage than group discussion. However, it still shows that open ended class is better than group discussion class.

The experimental class shows a higher mastery percentage at each stage compared to the control class. the stages of recognize assumption, the mastery percentage of the experimental class is $88,27 \%$ while the control class is $75,50 \%$. At the evaluate the argument stage, the experimental class is $74,49 \%$ while the control class is $53,50 \%$. At the stage of draw conlussion, the percentage of the experimental class is $23,47 \%$ while the control class is $9 \%$. Although the mastery of critical thinking skills is higher than that of the control class, the achievement of students' critical thinking skills at the draw conclussion level is still very poor because it is still below $30 \%$ of the total students. Therefore, further research is needed at this level.

Based on the results of data analysis with the Kolmogorov Smirnov test, both the data in the experimental class (open-ended approach) and control class (group discussion), both gave the $\mathrm{H} 0$ results accepted. This means that both are normally distributed and both classes have homogeneous variances. After this step, then we can proceed to test the hypothesis. Based on the results of the analysis by testing the independent sample t-test, the results obtained were that $\mathrm{H}_{0}$ was rejected. This means that mathematics learning using the Open-ended approach is more effective than mathematics learning using group discussion in terms of students' critical thinking skill. 


\section{Conclusion}

Based on the results of data analysis and discussion, it can be concluded as follows. The average score of the open-ended class is higher than the average score of the class with group discussion learning, that is $73,18>66,72$. It means the experimental class learning outcomes are higher than the control class. The critical thinking skills of open ended class include in high category, while group discussion class is in the middle category. The students who are in the high category in the open ended class are more than the group discussion class, that is $67,35 \%$ $>46 \%$.

The experimental class shows a higher mastery percentage at each stage compared to the control class. the stages of recognize assumption, the mastery percentage of the experimental class is $88,27 \%$ while the control class is $75,50 \%$. At the evaluate the argument stage, the experimental class is $74,49 \%$ while the control class is $53,50 \%$. At the stage of draw conlussion, the percentage of the experimental class is $23,47 \%$ while the control class is $9 \%$. in the paired t-test, the results obtained are sig. 2 tailed $0.041<0.05$ which means that using the open ended approach is more effective.

\section{Acknowledgement}

Our thanks go to the Kemenristek DIKTI through the beginner lecturer research program (PDP) which has provided opportunities and funding research. The PGSD students at Sarjanawiyata Tamansiswa Yogyakarta University who have collaborated in carrying out learning.

\section{References} [1] A Agoestanto et al Analysis of Mathematics Critical Thinking Students in Junior High http://iopscience.iop.org/article/10.1088/1742-6596/824/1/012052/pdf, 2017

[2] Nelson A Impact of Critical thinking on Performance in Mathematics among Senior Secondary School Students in Lagos State IOSR Journal of Research \& Method in Education (IOSR-JRME) Volume 3pp. 18 http://www.iosrjournals.org/iosrjrme/papers/Vol-3\%20Issue-5/D0351825.pdf?id=7370 , 2013

[3] Sumarna et al The Increase of Critical Thinking Skills through Mathematical Investigation Approach , J. Phys.: Conf. Ser. 812 012067pp. 1, 2017

[4] Kementerian Pendidikan dan Kebudayaan Kurikulum 2013, 2016.

[5] Rhosyida N Eksplorasi Kemampuan Pemecahan Masalah Matematis Mahasiswa PGSD J. Science Tech, 2016

[6] Peter E African Journal of Mathematics and Computer Science Research5 39 DOI: 10.5897/AJMCSR11.161, 2012

[7] Mayer E R Handbook of psychology, vol. 7 educational psychology (pp. 47-57). Hoboken : John Wiley \& Sons, Inc.pp. 50,2003 
[8] Takahashi A Communication as a Process for Students to Learn Mathematical. Accesed at 20 February 2016, from http://www.criced. tsukuba.ac.jp/math/ apec/apec2008/papers/PDF/14.Akihiko_Takahashi_USA.pdf. pp. 2 , 2008

[9] Al-Mubaid H 2014 International Journal of Advanced Corporate Learning 7 pp. 34-37 , 2008

[10] Ennis R H A Taxonomy of Critical Thinking Skills Critical Thinking,EdJ B Baron and R G Strenberg (Philadelphia: Franklin Institute press), 1986

[11] Rahmy Z et al Watson-Glaser's Critical Thinking Skills J. Phys.: Conf. Ser. 1028 012094http://iopscience.iop.org/article/10.1088/1742-6596/1028/1/012094/pdf , 2018

[12] Usman M A Menjadi Guru Profesional, Bandung: PT Remaja Rosdakarya, 2005

[13] Sawada T The Open-Ended Approach: A New Proposal for Teaching Mathematics (pp. 23-35). Reston VA: The National Council of Teachers of Mathematics, Inc., 1997

[14] Inprasitha M Open-Ended Approach And Teacher Education pp. 169-177 , 2006

[15] Cai J et al Problem solving in Chinese mathematics education: Research and practice, pp 39(September 2007), 459-474. https://doi.org/10.1007/s11858-007-0042-3, 2014 